\title{
Studying with the cloud: the use of online Web-based resources to augment a traditional study group format
}

\section{ABSTRACT}

Cloud-based applications such as Google Docs, Skype, Dropbox, and SugarSync are revolutionizing the way that we interact with the world. Members of the millennial generation (those born after 1980) are now becoming senior residents and junior attending physicians. We describe a novel technique combining Internet- and cloud-based methods to digitally augment the classic study group used by final-year residents studying for the Royal College of Physicians and Surgeons of Canada examination. This material was developed by residents and improved over the course of 18 months. This is an innovation report about a process for enhanced communication and collaboration as there has been little research to date regarding the augmentation of learner-driven initiatives with virtual resources.
\end{abstract}

Teresa Chan, MD; Serena Sennik, MA, MD; Amna Zaki, MD; Brendon Trotter, MD

\section{RÉSUMÉ}

Les applications fondées sur l'informatique en nuage, telles que Google Docs, Skype, Dropbox et SugarSync, révolutionnent la manière dont les gens interagissent avec le monde. Les membres de la génération $Y$ (ceux qui sont nés après 1980) deviennent maintenant résidents séniors ou médecins traitants juniors. Sera décrite ici une nouvelle technique associant Internet et l'infonuagique, en vue d'enrichir, par des ressources électroniques, le traditionnel groupe d'étude, une formule de révision utilisée par les résidents sortants afin de se préparer aux examens du Collège royal des médecins et chirurgiens du Canada. Le matériel a été conçu par des résidents et amélioré sur une période de 18 mois. II s'agit d'un rapport sur l'innovation à propos d'un processus visant à améliorer les communications et la collaboration puisqu'il s'est fait peu de recherche jusqu'à maintenant sur l'enrichissement des initiatives amorcées par les apprenants, à l'aide de ressources virtuelles.

Keywords: cloud, education, residents, study groups, technology, Web based
The millennials (i.e., "Generation Y" or "digital natives") are quickly becoming the predominant population within our residency programs. ${ }^{1}$ They have brought with them their love of technology and they frequently integrate these technologies into their daily lives. This generation arrived into postsecondary education shortly after the dawn of the Internet, and very few of them have ever journeyed to the library to research a topic or access information. ${ }^{2}$ For the past decade, much has been written about the "arrival" of the millennials to postsecondary education. ${ }^{3,4}$ The millennials have been entering the ranks of our residencies for nearly half a decade. They are using new technologies and techniques for increasing connectivity and productivity. This article describes the technology used by one group of postgraduate year 5 (PGY5) residents during their Royal College of Physicians and Surgeons of Canada (RC) examination year.

\section{RATIONALE}

The benefits of group studying have been shown to be significant. ${ }^{5,6}$ Benefits include changes in achievement, attitudes, and perceptions. ${ }^{6}$ With increasing numbers of residents in emergency medicine programs, scheduling synchronous study sessions becomes increasingly difficult for final-year residents.

In RC programs, residents often have program support to pursue academic enrichment during protected time; however, travel burdens and "real-life" scenarios may prevent attendance with in-person study groups. Electives away from one's home site and study

From the Division of Emergency Medicine, Department of Medicine, McMaster University, Hamilton, ON.

Correspondence to: Dr. Teresa Chan, Rm 254 McMaster Clinic, Hamilton General Hospital, 237 Barton Street East, Hamilton, ON L8L 2X2; teresa. chan@medportal.ca.

This article has been peer reviewed. 
group can derail study plans and change group dynamics. With increasing pressures from provincial bodies to expand training programs into regional campuses, fragmented RC programs will have pockets of smaller resident groups that cannot benefit from traditional collaborative studying events.

\section{DESCRIPTION OF THE INNOVATION}

We used an augmented reality approach to our normal study group. This study group used a number of freely accessible, Internet-based (dubbed "cloud-based") technologies to augment traditional methods for examination review. Like most other groups, the residents had dedicated study group sessions once per week, but due to various reasons (e.g., parental obligations, away electives, and traffic), it was difficult to consistently convene our study group with all members. A number of technologies were trialed to supplement our study group experience. The technologies that we used and our experiences with those platforms are summarized in Table 1.

Of note, the demographics of our group are important to understand how these methods may pertain to other learners. There were seven members of the study group, and the duration of the study group was 18 months. The median age of the participants was 31 years $(\mathrm{IQR}=29$ 33) at the beginning of the period. The median period that the residents were away from their core facility was 1 month. Several members had family dependents. No faculty members participated in this format.

\section{OUTCOMES}

Of great benefit was the opportunity to collaborate with colleagues at a distance. Study group members teleconferenced (31 times) from distant cities and were able to participate as active members, delivering and teaching review session content and engaging in discussions. For the first 9 months of the study group, the typical agenda consisted of two or three participants presenting review materials verbally, and the format was augmented by shared collaborative writing applications (CWAs) (e.g., Google Docs). Participants would listen and raise questions regardless of whether they attended personally or virtually. No novel agenda techniques were used to specifically change the study group protocols for virtual participants. One month prior to the $\mathrm{RC}$ examinations, several members used Skype to practice

Table 1. Technologies used to enhance our study group

\begin{tabular}{|c|c|c|c|}
\hline Platform & Description of platform & How it helped & Difficulties encountered \\
\hline $\begin{array}{l}\text { Google products, e.g., } \\
\text { Google Docs } \\
\text { https://docs.google.com/ } \\
\text { or Google drive } \\
\text { https://docs.google.com/ }\end{array}$ & $\begin{array}{l}\text { Acted as "virtual blackboard" } \\
\text { where participants could } \\
\text { collaborate on a common } \\
\text { document and watch } \\
\text { as others highlighted and } \\
\text { typed. } \\
\text { Acted also as the online database } \\
\text { and archive for developed } \\
\text { resources }\end{array}$ & $\begin{array}{l}\text { Google Docs allowed participants to } \\
\text { work in areas without a chalkboard to } \\
\text { collaborate and teach. } \\
\text { Google Drive allowed participants to } \\
\text { facilitate file sharing, and editing of } \\
\text { study group resources. } \\
\text { Enabled asynchronous collaboration } \\
\text { (i.e., people could edit and view others' } \\
\text { contributions at different times) } \\
\text { We also used a Google spreadsheet } \\
\text { to schedule our sessions and maintain } \\
\text { our progress along our self-defined } \\
\text { curriculum. }\end{array}$ & $\begin{array}{l}\text { Our seven laptops would sometimes } \\
\text { overwhelm our local hospital-based } \\
\text { WIFI hub. } \\
\text { Due to bandwidth limitations, this } \\
\text { sometimes made it difficult to edit } \\
\text { documents together in real time. } \\
\text { At times, some netbook users had } \\
\text { difficulty interfacing with the Web- } \\
\text { based application. } \\
\text { We ultimately delegated a single } \\
\text { person to edit the documents, while } \\
\text { others would just view. }\end{array}$ \\
\hline $\begin{array}{l}\text { Skype } \\
\text { (http://www.skype.com } \\
\text { or } \\
\text { Google Hangouts } \\
\text { http://www.google.com/+/ } \\
\text { learnmore/hangouts/ }\end{array}$ & $\begin{array}{l}\text { Both Skype and Google Hangouts } \\
\text { allows users with a webcam (often } \\
\text { now embedded within laptops) to } \\
\text { interface with others if they are } \\
\text { unable to attend in person. }\end{array}$ & $\begin{array}{l}\text { Allowed multiple users to "skype in" } \\
\text { to study group and continue reviewing } \\
\text { material. } \\
\text { Later in the year, allowed smaller } \\
\text { groups to review cases and } \\
\text { run mock oral scenarios without losing } \\
\text { valuable time for extensive travel. }\end{array}$ & $\begin{array}{l}\text { If the internet connection was slow } \\
\text { we could not always hear or interact } \\
\text { well. } \\
\text { Video chatting with more than } 1 \\
\text { person on Skype required additional } \\
\text { payment. } \\
\text { Significant improvements have been } \\
\text { made to Google Hangouts since the } \\
\text { end of reported period (2011-2013) }\end{array}$ \\
\hline $\begin{array}{l}\text { DropBox } \\
\text { http://www.dropbox.com }\end{array}$ & $\begin{array}{l}\text { Used to share larger files by } \\
\text { our group but can also be used } \\
\text { to share study-group resources. }\end{array}$ & Allowed us to facilitate file sharing. & $\begin{array}{l}\text { If two people open the same file, } \\
\text { there will be two new copies saved } \\
\text { as discrepant files. } \\
\text { Does not allow for easy merger of } \\
\text { altered files. }\end{array}$ \\
\hline
\end{tabular}


for oral examinations (five sessions). One member even regularly (nine occasions) coordinated schedules with a colleague in British Columbia (three time zones away) to review materials.

The participants wrote and shared 162 study guides based on topics found in key textbooks (e.g., Rosen ${ }^{7}$ and Tintinalli ${ }^{8}$ ). They gathered essential guidelines or other key literature into one searchable database (Google Drive). There were 31 (of 128) sessions where at least one member was unable to attend but was able to be present virtually. There were only 18 of 128 sessions (14\%) where members were not able to participate (in person or virtually), which would have been 49 of 128 (33\%) had it not been for the technology.

The members of the study group had a 100\% pass rate, although it is impossible to determine if the augmented study group technique contributed to this result.

\section{DISCUSSION}

The participants had great success in achieving a higher participation rate by digitally enhancing a standard, live study group format $(14 \%$ v. $33 \%$ absenteeism in 18 months). Although there is some literature about teacher-driven use of collaborative technologies, ${ }^{9,10}$ learner-driven incorporation of cloudbased technologies by residents has not been well reported. One recently proposed study protocol explores CWA use for final-year emergency medicine residents, but the results have yet to be published. ${ }^{11}$

Even with millennial learners, there was a substantial technology-related barrier to the uptake of this format. ${ }^{12}$ This unease with the technology is consistent with recent literature, ${ }^{12}$ implying that teachers should not assume technological comfort due to age. Initially, there was a steep learning curve for those in the group, but in the spirit of true collaborative learning, these barriers were overcome with peer help.

The potential for harnessing and applying technologies must be explored. This report highlights new study areas in medical education research. One would be to test video chat for oral examinations. From their disparate locations, participants noted that they were able to view their peers for a mock oral examination case and provide feedback, commenting on body language or other visual cues. More research is required to know if virtual sessions can replace live oral examination sessions or if they are simply supplementary tools.

\section{SUMMARY}

Digitally augmenting traditional study groups with free online resources is possible. Harnessing technology may even enhance and increase opportunities for sharing resources in both synchronously (e.g., video chat-based opportunities, such as through Skype) and asynchronously (e.g., amassing a shared database of resources, such as Google Docs).

Acknowledgements: We would like to thank the other members of the "Group of Seven" from McMaster University (Drs. Caillin Langmann, Cherie Adams, and Julian Owen) for their support. We would also like to thank all the faculty members at McMaster University, as well as all those at other institutions, such as the Children's Hospital of Eastern Ontario, who helped our cohort throughout our examination preparations.

Competing interests: None declared.

\section{REFERENCES}

1. Selwyn N. The digital native-myth and reality. $N$ Info Perspect 2009;61:364-79.

2. Holliday $W, \mathrm{Li}$ Q. Understanding the millennials: updating our knowledge about students. Reference Services Review 2004;32:356-66, doi:10.1108/00907320410569707.

3. Morgan P, Pardue KT. Millennials considered: a new generation, new approaches, and implications for nursing education. Nurs Educ Perspect 2008;29:74-9.

4. DeBard R. Millennials coming to college. New Directions for Student Services 2004;106:33-45, doi:10.1002/ss.123.

5. Yamarik S. Does cooperative learning improve student learning outcomes? $\mathcal{f}$ Econ Educ 2007;38:259-77, doi: 10.3200/JECE.38.3.259-277.

6. Kyndt E, Raes E, Lismont B, et al. A meta-analysis of the effects of face-to-face cooperative learning. Do recent studies falsify or verify earlier findings? Educational Research Review, Available at: http://www.sciencedirect.com/science/article/ pii/S1747938X13000122 (accessed March 6, 2013).

7. Marx J, Hockberger R, Walls R. Rosen's emergency medicine: concepts and clinical practice. Philadelphia: Elsevier Health Sciences; 2013.

8. Tintinalli JE, Stapczynski JS, Ma OJ. Tintinalli's emergency medicine: a comprehensive study guide. 7th ed. New York: McGraw-Hill Medical; 2011.

9. George P, Dumenco L, Dollase R, et al. Introducing technology into medical education: two pilot studies. Pat Educ Couns 2013;93:522-4, doi:10.1016/j.pec.2013.04.018.

10. Wang AT, Sandhu NP, Wittich CM, et al. Using social media to improve continuing medical education: a survey of course participants. Mayo Clin Proc 2012;87:1162-70, doi: 10.1016/j.mayocp.2012.07.024.

11. Archambault PM, Blouin D, Poitras J, et al. Emergency medicine residents' beliefs about contributing to a Google Docs presentation: a survey protocol. Inform Prim Care 2011; 19:207-16. 
12. Kirschner PA, van Merriënboer JJ. Do learners really know best? Urban legends in education. Educational Psychologist 2013;48:169-183. Available at: http://www.tandfonline.com/
doi/abs/10.1080/00461520.2013.804395\#.Uq5YTo1Q1j8

(accessed Novemer 15, 2013), doi:10.1080/00461520. 2013.804395 . 